ISSN 1392-3196 / e-ISSN 2335-8947

Zemdirbyste-Agriculture, vol. 104, No. 4 (2017), p. 321-328

DOI 10.13080/z-a.2017.104.041

\title{
The importance and profitability of farmyard manure application to an organically managed crop rotation
}

\author{
Malle JÄRVAN, Raivo VETTIK, Kalvi TAMM \\ Estonian Crop Research Institute \\ J. Aamisepa 1, 48309 Jõgeva, Estonia \\ E-mail: malle.jarvan@etki.ee
}

\begin{abstract}
The benefit from organically cultivated crops is strongly related to the maintenance of soil fertility based to a great extent on the soil organic matter content. Farmyard manure (FYM) is one of the more valuable organic fertilizers maintaining soil fertility in the systems of alternative agriculture. To investigate the influence of FYM from several aspects, a field experiment was carried out on a sandy loam Albic Stagnic Luvisol (LVab-st). A five-year crop rotation (potato $\rightarrow$ oats $\rightarrow$ barley $\rightarrow$ clover $\rightarrow$ rye) was organically managed without manure (ORG) and with manure (ORGFYM) treatments. $8.3 \mathrm{t} \mathrm{ha}^{-1}$ of organic dry matter as solid cattle farmyard manure was spread prior to the rye stubble ploughing for potato grown the next year. For the both treatments, the whole mass of clover and straw was ploughed into the soil. During a seven-year experimental period, no significant changes were found in the soil organic carbon $\left(\mathrm{C}_{\mathrm{org}}\right)$ content. For the ORG treatment, a significant $(P<0.05)$ decrease in potassium, copper and boron contents in the soil occurred. The application of FYM significantly increased the contents of phosphorus and magnesium in the soil. Under the influence of FYM, the yields of potato, oats and barley increased by 52, 23 and $10 \%$, respectively; this allowed us to gain an extra $30 \mathrm{GJ}$ metabolizable energy during the crop rotation. The economic calculations showed that the application of farm own manure was profitable even if the yield was sold as a non-organic product. If the yield is sold as an organic product, it would be profitable if the transportation distance of purchased manure to the fields is up to $15 \mathrm{~km}$.
\end{abstract}

Key words: crop yields, organic carbon, profit, soil nutrients, solid cattle manure.

\section{Introduction}

Organic agriculture is a production system which relies on ecosystem management and ecological processes rather than on the external flow of agricultural inputs (Foissy et al., 2013). In the organic farming systems, it is important to improve soil fertility and at the same time to protect and improve soil physical condition for its healthy functioning. Maintenance and improvement of soil potential fertility are closely related to the maintenance of soil organic matter and organic carbon balance (Bakšiené et al., 2014). Soil organic matter (SOM) plays a crucial role in maintaining sustainability of cropping systems by improving soil physical, chemical and biological properties (Diacono, Montemurro, 2010; Fageria, 2012). Organic farming systems are generally associated with increased biological activity and increased below-ground biodiversity. The main impacts of biological fertility do not result from the systems by themselves, but are related to the amount and quality of the soil organic matter (Stockdale, Watson, 2009).

Organic farming has become a part of the global agricultural industry and therefore organic products are traded not just between farms and regions but between countries and continents. Inevitably, large amounts of nutrients are exported from farms as part of this process. These farms can only continue to produce acceptable quantities of quality food if these nutrients are replaced. This is perhaps easiest for nitrogen where biological fixation by legumes can be harnessed to provide the engine for crop production (Wattson, Stockdale, 2013). For other major and micronutrients more consideration needs to be given to acceptable sources for organic production. On organic farms, where the importation of materials to build and maintain soil fertility is restricted, it is important that a balance between inputs and outputs of nutrients is achieved to ensure both short-term productivity and long-term sustainability (Watson et al., 2002; Foissy et al., 2013).

The development of the organic sector has induced a spatial decoupling of livestock and crop production. This has increased the flow of nutrients that occurs between farms (Foissy et al., 2013; Wattson, Stockdale, 2013). From a point of principle there is an expectation that mixed farming will be more prevalent within organic production, with a degree of reliance on home produced feed and fodder (Wattson, Stockdale, 2013). Integrated crop-livestock systems should improve

Please use the following format when citing the article:

Järvan M., Vettik R., Tamm K. 2017. The importance and profitability of farmyard manure application to an organically managed crop rotation. Zemdirbyste-Agriculture, 104 (4): 321-328 DOI 10.13080/z-a.2017.104.041 
soil quality, SOM dynamics and crop yield (Maughan et al., 2009). The sustainability of stockless organic farming systems is questioned, noticeably those that were located in regions where resources of organic matter are scarce. Only farming systems producing large quantities of manure or which purchased feed showed balanced nutrient budgets (Foissy et al., 2013). Specialization within organic agriculture in many Western European countries has led to the decoupling of crop and animal systems, resulting in a shortfall in manure fertilizers on most farms and a surplus on others. One solution to this problem has been the establishment of collaborative partnerships between specialized organic farms for manure exchange (Asai, Langer, 2014).

Manure from cattle and other livestock is an important source of nutrients in the livestock-intensive regions. Farmyard manures are the major source of nutrient supply also on small farm holdings (Fageria, 2012). Manure has long been considered a desirable soil amendment, and reports of its effects on soil properties are numerous. Different animal manures have been used as a source of nutrients for crops cultivated. As reported by Smith and Williams (2016), cattle manure comprised $80 \%$ of the total UK animal livestock manure production during the housing period, there at about $53 \%$ of this was estimated to be as solid, mainly straw-based cattle manure. In the intensive livestock farms with a limited area of agricultural land there is a risk of over-fertilizing with manure, which may result in increased nutrient leaching and groundwater contamination. The long-term lysimetric experiments on a sandy loam Luvisol showed that the intensive application of straw-based cattle manure (at $300 \mathrm{~kg} \mathrm{ha}^{-1} \mathrm{~N}$ rate annually) resulted in great amounts of nitrogen and calcium leached from the soil (Tripolskaja et al., 2016).

Regular addition of organic materials, particularly the composted ones, increased soil physical fertility, mainly by improving aggregate stability and decreasing soil bulk density (Diacono, Montemurro, 2010). The impact of animal manure depends on soil texture. According to Dunjana et al. (2012), the addition of cattle manure resulted in significant $(P<0.01)$ increases in soil organic carbon (SOC), macro-aggregate stability and aggregate protected carbon in clay soils. However, the addition of cattle manure on sandy soils, in contrast, increased significantly $(P<0.05)$ only SOC but had no impact on soil bulk density and aggregate stability. Addition of animal manure may increase biodiversity in the soil, thereby causing alteration in composition, size, and activity of soil microorganisms and enzyme activities (Watts et al., 2010).

The aim of the current work was to show a versatile influence of solid cattle farmyard manure (FYM) applied for an organically managed crop rotation. The study investigated the influence of FYM on the crop yields and metabolizable energy from the crop rotation, changes in the soil agrichemical properties; the cost-benefit (profitability) for the FYM utilization was calculated. The following hypothesis was tested: the application of FYM in organically managed crop rotation is environmentally friendly and economically profitable.

\section{Materials and methods}

Site and soil description. The field experiment was performed in Central-Estonia at Olustvere $\left(58^{\circ} 33^{\prime} \mathrm{N}\right.$, $25^{\circ} 34^{\prime}$ E) during 2008-2014. The soil of the experimental site is an Albic Stagnic Luvisol (LVab-st) according to the
WRB 2014 classification. The texture of the soil is sandy loam (61.6\% sand, $30.4 \%$ silt and $8.0 \%$ clay). Formerly, in this area a five-course crop rotation was cultivated according to the principles of organic farming. During 2002-2007, this area was cultivated without the use of any kind of fertilizers. At the end of April 2008, before experiment set up, the carefully mixed soil samples from the $0-20 \mathrm{~cm}$ soil layer were taken from the randomly selected points of the 6 ha experimental area. The soil samples were analysed according to the Mehlich-3 method (Mehlich, 1984) at the Agricultural Research Centre, Estonia. As the average of 15 soil samples analysed, the main agrichemical parameters were the following: $203 \mathrm{mg} \mathrm{kg}^{-1} \mathrm{P}$ (high level), $137 \mathrm{mg} \mathrm{kg}^{-1} \mathrm{~K}$ (medium), $1278 \mathrm{mg} \mathrm{kg}^{-1} \mathrm{Ca}$ (medium) and $67 \mathrm{mg} \mathrm{kg}^{-1}$ $\mathrm{Mg}$ (low); $\mathrm{pH}_{\mathrm{KCl}} 6.1$.

Experimental design. In 2008, the crop rotation was modified and established as follows: winter rye (Secale cereale L. 'Elvi', seeding rate 450 seeds per $1 \mathrm{~m}^{2}$ ), potato (Solanum tuberosum L. 'Laura', 5 tubers per $\mathrm{m}^{2}$ ), oats (Avena sativa L. 'Jaak', 400 seeds per $1 \mathrm{~m}^{2}$ ), barley (Hordeum vulgare L. 'Anni', 300 seeds per $\mathrm{m}^{2}$ ) with undersown red clover (Trifolium pratense L. 'Jõgeva 433') and red clover. The size of each field was 1.2 ha, which was divided into three equal parts ( 0.4 ha) between the cultivation methods. Since 2007, the following treatments were carried out: organic without manure (ORG), organic with solid cattle farmyard manure (ORGFYM) and conventional where solid cattle manure and mineral fertilizers were used (CONFYM). For the present work, we will compare only the ORG and ORGFYM treatments and the data of the CONFYM treatment are not used.

The tillage method in both organic treatments was the mouldboard ploughing to a depth of $20 \mathrm{~cm}$ in autumn. On the cereal fields, the stubble breaking after crop harvesting was carried out. In both treatments, clover was cut and ploughed into the soil in the beginning of July. Straw and crop residues were not removed from the field. Weeds were controlled in the oats and barley fields after sowing and in the rye field at the end of April by spring-tine harrowing. In the potato field, the interrows were harrowed and cultivated two and three times, respectively. For the ORGFYM treatment, in the rye field after the rye harvesting and prior to the autumn ploughing straw-based solid cattle farmyard manure (FYM) at the rate of $60 \mathrm{t} \mathrm{ha}^{-1}$ fresh weight was applied for potato grown the next year. Every year during 2008-2012, the content of nutrients in cattle manure was determined before the application in the soil (Table 1). Calculated on the basis of the long-term average contents of nutrients in FYM, for the 5-year crop rotation of the ORGFYM treatment the following amounts of nutrients were applied by FYM into the soil: $286 \mathrm{~kg} \mathrm{ha}^{-1}$ nitrogen $(\mathrm{N}), 61 \mathrm{~kg} \mathrm{ha}^{-1}$ phosphorus (P), $166 \mathrm{~kg} \mathrm{ha}^{-1}$ potassium (K), $130 \mathrm{~kg} \mathrm{ha}^{-1}$ calcium $(\mathrm{Ca})$ and $56 \mathrm{~kg} \mathrm{ha}^{-1}$ magnesium $(\mathrm{Mg})$; trace elements: $286 \mathrm{~g} \mathrm{ha}^{-1}$ copper $(\mathrm{Cu}), 1224 \mathrm{~g} \mathrm{ha}^{-1}$ manganese (Mn) and $201 \mathrm{~g} \mathrm{ha}^{-1}$ boron (B).

Soil sampling and analysis. Every year in September, after crop harvesting and before manure application in the rye stubble field, from both organic treatments of all rotation fields the soil samples for chemical analyses were taken. Every sample was collected from 45 randomly selected points from the $0-20 \mathrm{~cm}$ layer using an auger with a $1 \mathrm{~cm}$ diameter. The soils were analysed for $\mathrm{P}, \mathrm{K}, \mathrm{Ca}, \mathrm{Mg}, \mathrm{Mn}$ and $\mathrm{Cu}$ by the 
Table 1. The content of macro- and microelements in cattle manure applied in 2008-2012

\begin{tabular}{|c|c|c|c|c|c|c|c|c|c|}
\hline \multirow{3}{*}{ Year } & \multirow{3}{*}{$\begin{array}{c}\text { Dry matter } \\
\%\end{array}$} & \multicolumn{8}{|c|}{ Content in fresh matter } \\
\hline & & \multicolumn{5}{|c|}{$\mathrm{kg} \mathrm{t}^{-1}$} & \multicolumn{3}{|c|}{$\mathrm{g} \mathrm{t}^{-1}$} \\
\hline & & $\mathrm{N}$ & $\mathrm{P}$ & $\mathrm{K}$ & $\mathrm{Ca}$ & $\mathrm{Mg}$ & $\mathrm{Cu}$ & $\mathrm{Mn}$ & B \\
\hline 2008 & 16.6 & 4.72 & 0.75 & 2.92 & 2.17 & 0.74 & 3.40 & 16.8 & 3.09 \\
\hline 2009 & 17.6 & 5.30 & 1.20 & 2.70 & 1.50 & 0.71 & 0.85 & 16.9 & 1.60 \\
\hline 2010 & 15.1 & 6.30 & 1.20 & 2.80 & 2.00 & 1.30 & 5.00 & 20.6 & 4.50 \\
\hline 2011 & 17.6 & 3.45 & 0.80 & 3.20 & 2.53 & 0.94 & 9.81 & 20.0 & 2.57 \\
\hline 2012 & 16.3 & 4.05 & 1.15 & 2.25 & 2.66 & 1.02 & 4.81 & 27.6 & 4.99 \\
\hline 2008-2012 & 16.6 & 4.76 & 1.02 & 2.77 & 2.17 & 0.94 & 4.77 & 20.4 & 3.35 \\
\hline
\end{tabular}

Mehlich-3 method and for B according to Berger and Truog (1939) at the Agricultural Research Centre located at Saku, Estonia. Soil $\mathrm{pH}$ in $1 \mathrm{M} \mathrm{KCl}$ suspension was measured at the ratio of $10 \mathrm{~g}: 25 \mathrm{ml}$. Organic carbon $\left(\mathrm{C}_{\mathrm{org}}\right)$ content in the soil was determined after dry combustion by elementary analysis (ISO 10694:1995. Soil quality - Determination of organic and total carbon after dry combustion (elementary analysis)). For microbiological analyses, the soils were sampled separately. The procedure of soil sampling and methods for its microbiological testing carried out in the Microbiological Laboratory of the Agricultural Research Centre, Estonia are described in Järvan and Edesi (2015). The dehydrogenase activity in the soils according to Tabatabai (1982) was tested by Liina Edesi in the laboratory of the Estonian Crop Research Institute.

Crop harvesting and handling. At the maturity stage, before cereal plots were harvested by a combine, the grain yields for the both organic treatments were calculated on the basis of sheaves taken from the $1 \mathrm{~m}^{2}$ area in four replications. The yields of cereals were quantified on $86 \%$ dry matter content. For potato, the tubers of 10 plants in three replications were sampled by hand, and the yields of marketable tubers $(>35 \mathrm{~mm})$ per hectare were calculated. In order to summarize the total production of the crop rotation and to compare it for the both organic treatments, the values of crop yields were calculated in the units of metabolizable energy (ME) according to the guide (Oll, Tölp, 1997). The average samples of potato tubers and cereal (rye, oat and barley) grains were composed and submitted for the chemical analysis at the Biochemistry Laboratory of the Estonian University of Life Sciences. The contents of phosphorus, calcium and magnesium were determined in Kjeldahl digestion by Fiastar 5000 (Foss, Denmark). Potassium was determined by the flame photometric method (AOAC, 1990).

Nutrient balances. On the basis of yields and chemical analysis data, the nutrient removal with yields from the rotation fields for the both treatments was evaluated yearly. For the 5-year crop rotation, the average (2008-2014) nutrient balances for P, K, Ca and Mg were also calculated. Balances were calculated at the field level as a difference between input and output. For the ORG treatment no nutrients were added into the soil, i.e. the input was equal to zero. For the ORGFYM treatment, the input constituted amounts of nutrients applied with cattle manure for potato, i.e. $61 \mathrm{~kg} \mathrm{ha}^{-1} \mathrm{P}, 166 \mathrm{~kg} \mathrm{ha}^{-1} \mathrm{~K}, 130 \mathrm{~kg}$ $\mathrm{ha}^{-1} \mathrm{Ca}$ and $56 \mathrm{~kg} \mathrm{ha}^{-1} \mathrm{Mg}$ during the 5-year crop rotation. Concerning output, there only the nutrient removal with harvested products was taken into consideration; other factors (potential leaching, etc.) were not considered. For crops the calculation of nutrient export was based on the amounts of $\mathrm{P}, \mathrm{K}, \mathrm{Ca}$ and $\mathrm{Mg}$ that were removed with the harvested dry matter from four fields (from clover field nothing was removed) during the 5-year crop rotation.
Farmyard manure profitability. The costs and incomes for the additional production during the crop rotation, resulting from the use of FYM, were calculated. Additional costs connected with use of FYM are: 1) cereals - extra yield harvesting, transportation, drying and storage $\left.\left(52.7 € \mathrm{t}^{-1}\right) ; 2\right)$ potato - extra yield harvesting, transportation and sorting $\left(44.1 € \mathrm{t}^{-1}\right)$; the storage loss of potato is considered 20\% (Oinus, 2012). Manure handling costs (loading, transportation and spreading) are calculated by taking into account the transport distance (Tamm, Vettik, 2008; Koik et al., 2009). By transport distance $1 \mathrm{~km}$ is assumed that the manure is company's own production and its monetary value was not taken into account. For transport distance of 5-20 km, to the manure handling cost are added also the cost associated with manure monetary value $-6.9 € \mathrm{t}^{-1}$. The monetary value of manure is calculated according to plant nutrient elements $(\mathrm{N}, \mathrm{P}$ and $\mathrm{K}$ ) content in manure (Table 1) and price of the elements. The nutrient prices are derived from mineral fertilizer prices and are as follows: $\mathrm{N}-0.82 € \mathrm{~kg}^{-1}, \mathrm{P}-$ $1.85 € \mathrm{~kg}^{-1}$ and $\mathrm{K}-0.75 € \mathrm{~kg}^{-1}$ (Tamm, Vettik, 2011).

Weather conditions. Meteorological conditions were assessed according to the data from Viljandi Meteorological Station, Estonia (Table 2). During the experimental period, the weather conditions in the vegetation period (from April to September) were quite different. The growing seasons 2008, 2012 and 2014 were very rainy but 2011 and 2013 were extremely dry and warm. In 2008, 2010 and 2014, the end of summer was characterized by very great amounts of precipitation (total in August 143-177 mm) which temporarily caused short-term flooding of the soil. The spring of 2009 differed among other springs with less precipitation, because it rained only $34 \mathrm{~mm}$ in total in April and May. The vegetation periods of 2008 and 2012 were the coldest, with $12.5^{\circ} \mathrm{C}$ and $12.4^{\circ} \mathrm{C}$ as the average for the six months' period. In July 2010, 2011 and 2014, extraordinarily hot air temperatures prevailed, up to $22.4^{\circ} \mathrm{C}$ as the monthly average. Unexpectedly warm were May and June of 2013, up to $3^{\circ} \mathrm{C}$ higher than the multi-annual average.

Statistical analysis. All results were based on 3-5 replicates. The data were evaluated by analysis of variance $(A N O V A)$. The Tukey-Kramer honestly significant difference (HSD) test was used, using the software JMP 5.0.1.2 (2002; SAS Institute, USA).

\section{Results and discussion}

Soil agrichemical properties. Solid manure is one of the more valuable organic fertilizers maintaining soil fertility in the systems of alternative agriculture. Its composition is abundant in the materials required by plants and a substantial part of the organic materials present in manure are already humified to some extent. Different macro- and microelements, physiologically active materials and microorganisms are incorporated 
Table 2. Monthly total precipitation and average air temperatures during 2008-2014

\begin{tabular}{|c|c|c|c|c|c|c|c|c|}
\hline \multirow{2}{*}{ Month } & \multicolumn{7}{|c|}{ Year } & \multirow{2}{*}{$\begin{array}{c}\text { Average } \\
1981-2010\end{array}$} \\
\hline & 2008 & 2009 & 2010 & 2011 & 2012 & 2013 & 2014 & \\
\hline \multicolumn{9}{|c|}{ Precipitation $\mathrm{mm}$} \\
\hline January & 65 & 42 & 22 & 75 & 88 & 41 & 42 & 62 \\
\hline February & 82 & 23 & 49 & 30 & 49 & 37 & 28 & 43 \\
\hline March & 69 & 43 & 47 & 25 & 55 & 22 & 35 & 42 \\
\hline April & 52 & 17 & 35 & 11 & 53 & 44 & 15 & 36 \\
\hline May & 22 & 17 & 53 & 58 & 62 & 75 & 88 & 48 \\
\hline June & 119 & 91 & 77 & 22 & 81 & 21 & 108 & 87 \\
\hline July & 48 & 136 & 43 & 66 & 92 & 51 & 72 & 83 \\
\hline August & 177 & 95 & 143 & 84 & 107 & 78 & 155 & 91 \\
\hline September & 66 & 66 & 108 & 68 & 79 & 14 & 30 & 67 \\
\hline October & 91 & 128 & 49 & 54 & 91 & 51 & 56 & 81 \\
\hline November & 76 & 77 & 101 & 42 & 94 & 83 & 23 & 64 \\
\hline December & 49 & 99 & 111 & 126 & 62 & 61 & 92 & 60 \\
\hline Total & 917 & 833 & 839 & 661 & 915 & 578 & 744 & 764 \\
\hline \multicolumn{9}{|c|}{ Temperature ${ }^{\circ} \mathrm{C}$} \\
\hline January & -1.0 & -2.8 & -13.3 & -4.2 & -5.1 & -6.6 & -7.9 & -4.4 \\
\hline February & 0.8 & -5.0 & -7.9 & -10.7 & -10.3 & -3.0 & -0.4 & -5.1 \\
\hline March & 0.4 & -1.2 & -1.6 & -1.5 & 0 & -6.8 & 2.4 & -1.0 \\
\hline April & 7.2 & 6.0 & 6.0 & 6.7 & 4.9 & 3.6 & 6.7 & 5.3 \\
\hline May & 10.8 & 11.6 & 12.3 & 11.3 & 11.8 & 14.5 & 11.8 & 11.3 \\
\hline June & 14.6 & 13.9 & 14.7 & 17.8 & 13.7 & 18.0 & 13.7 & 14.9 \\
\hline July & 16.5 & 17.2 & 22.4 & 20.4 & 18.2 & 17.8 & 19.7 & 17.5 \\
\hline August & 15.8 & 15.7 & 18.5 & 16.4 & 15.2 & 17.2 & 17.0 & 16.1 \\
\hline September & 10.0 & 13.0 & 11.2 & 12.8 & 12.3 & 11.4 & 12.1 & 11.0 \\
\hline October & 8.4 & 4.1 & 4.1 & 7.4 & 5.9 & 7.1 & 5.7 & 6.0 \\
\hline November & 2.5 & 2.4 & 0.3 & 4.0 & 2.7 & 4.1 & 1.4 & 0.6 \\
\hline December & -0.7 & -4.7 & -7.9 & 1.6 & -6.7 & 1.8 & -1.2 & -3.1 \\
\hline Average & 7.1 & 5.9 & 4.9 & 6.8 & 5.2 & 6.6 & 6.8 & 5.8 \\
\hline
\end{tabular}

into soil together with the organic material (Masilionytè, Maikštenienè, 2016).

Organic carbon $\left(C_{\text {org }}\right)$. The $\mathrm{C}_{\text {org }}$ content of soil changes very slowly. According to Körschens et al. (1998), the annual changes of the $\mathrm{C}_{\text {org }}$ content amounted only to about $0.01 \% \mathrm{C}_{\text {org }}$, even under extreme changes of the fertilizing system. The long-term application of FYM, as a rule, increased the $\mathrm{C}_{\text {ors }}$ content of the soil (Dunjana et al., 2012; Fageria, 2012; Simon, Czakó, 2014; Blanchet et al., 2016). However, as showed by Scherer et al. (2011), after 45 years of repeated applications of FYM (every second year 4.5 and $9.0 \mathrm{tha}^{-1}$ on a dry weight basis) the $\mathrm{C}_{\text {org }}$ content did not significantly differ from the control.

In our experiment, which lasted only seven years, no significant $(P<0.05)$ changes in the soil $\mathrm{C}_{\text {or }}$ content occurred. In the $\mathrm{C}_{\text {org }}$ content, being at the start (2008) of the experiment $1.56 \%$ as the average for the 5-year crop rotation, only a small tendency to the decrease appeared for the ORG treatment. However, for the ORGFYM treatment, where $8.3 \mathrm{tha}^{-1}$ of organic dry matter as cattle manure was incorporated into the soil per 5-year crop rotation, a light tendency to the increase $(1.56 \rightarrow 1.66 \%)$ of $\mathrm{C}_{\text {ri }}$ in the soil appeared. The duration of our study was too short for looking at significant changes in the soil $\mathrm{C}_{\text {org }}$ content.

Content of nutrients in the soil. To assess the trend in the content of plant nutrients in the soil as affected by different organic managements, we calculated their mean values in the soils from all five fields of the crop rotation together for both treatments (Table 3).

The content of Mehlich-3 extractable phosphorus $\left(\mathrm{P}_{\mathrm{Me} 3}\right)$ in the soil of the experiment area was high - about $200 \mathrm{mg} \mathrm{kg}^{-1}$ (Table 3). For the ORG treatment, the $\mathrm{P}_{\mathrm{Me}}$ contents at the beginning (2008) and at the end (2014) of the experiment were practically similar. For the ORGFYM treatment, the content of $\mathrm{P}_{\mathrm{Me} 3}$ in the soil was

Table 3. The content of nutrient elements in the soil $\left(\mathrm{mg} \mathrm{kg}^{-1}\right)$ at the beginning (2008) and at the end (2014) of the experiment

\begin{tabular}{ccccc}
\hline \multirow{2}{*}{ Nutrient element } & Treatment & 2008 & 2014 & Change \\
\hline \multirow{2}{*}{ Phosphorus (P) } & ORG & 209 & 211 & $+2 \mathrm{~ns}$ \\
& ORGFYM & 195 & 210 & $+15^{*}$ \\
\hline \multirow{2}{*}{ Potassium (K) } & ORG & 133 & 103 & $-30^{*}$ \\
& ORGFYM & 140 & 152 & $+12 \mathrm{~ns}$ \\
\hline \multirow{2}{*}{ Magnesium (Mg) } & ORG & 64 & 75 & $+11 \mathrm{~ns}$ \\
& ORGFYM & 64 & 99 & $+35^{*}$ \\
\hline \multirow{2}{*}{ Calcium (Ca) } & ORG & 1148 & 1168 & $+20 \mathrm{~ns}$ \\
& ORGFYM & 1224 & 1222 & $-2 \mathrm{~ns}$ \\
\hline \multirow{2}{*}{ Copper (Cu) } & ORG & 1.98 & 1.78 & $-0.20^{*}$ \\
& ORGFYM & 1.70 & 1.52 & $-0.18^{*}$ \\
\hline \multirow{2}{*}{ Manganese (Mn) } & ORG & 118 & 120 & $+2 \mathrm{~ns}$ \\
& ORGFYM & 117 & 116 & $-1 \mathrm{~ns}$ \\
\hline \multirow{2}{*}{ Boron (B) } & ORG & 0.44 & 0.33 & $-0.11^{*}$ \\
& ORGFYM & 0.45 & 0.38 & $-0.07 \mathrm{~ns}$ \\
\hline
\end{tabular}

ORG - organic without manure, ORGFYM - organic with farmyard cattle manure; * $-P<.05$, ns - not significant

significantly $(P<0.05)$ increasing over this period. It must be mentioned that in this treatment $61 \mathrm{~kg} \mathrm{ha}^{-1}$ of total $\mathrm{P}$ with cattle manure was given for the 5-year crop rotation and $42.7 \mathrm{~kg} \mathrm{ha}^{-1}$ of P (Table 5) was removed with yields at this period. According to Parham et al. (2002), the effect of cattle manure applied at the rate and frequency close to these of our experiment, manure-P is relatively more mobile than inorganic fertilizer-P. Long-term application of cattle manure promoted also microbiological activities and P cycling in the soil (Parham et al., 2002). For the 7-year period of our experiment, also the content of ammonium 
lactate extractable phosphorus $\left(\mathrm{P}_{\mathrm{AL}}\right)$ which in parallel with Mehlich-3 extraction in the soils was determined, showed an increase (from 68 up to $82 \mathrm{mg} \mathrm{kg}^{-1}$ ) for the ORGFYM treatment (Järvan et al., 2017).

The content of Mehlich-3 extractable potassium $\left(\mathrm{K}_{\mathrm{Me} 3}\right)$ in the soil of the ORG treatment decreased significantly $(P<0.05)$ over seven years of the experiment. However, the increasing tendency of $\mathrm{K}_{\mathrm{Me} 3}$ content for the ORGFYM treatment appeared. Similar tendencies became evident for the content of ammonium lactate extractable potassium $\left(\mathrm{K}_{\mathrm{AL}}\right)$ : it was decreasing for the ORG treatment, and increasing for the ORGFYM treatment (Järvan et al. 2017). Bakšienè et al. (2014), investigating the dynamics of soil chemical properties by the soil type and crop rotation similar to our experiment, also have found that for the extensive (without nutrient input) farming system the contents of mobile potassium $\left(\mathrm{K}_{\mathrm{AL}}\right)$ in the soil decreased over years. According to Wortman et al. (2012), the soils of animal manure-based organic systems contain more potassium and other macro- and trace elements than the soils of forage-based organic systems.

The content of Mehlich-3 extractable calcium $\left(\mathrm{Ca}_{\mathrm{Me} 3}\right)$ in the soils of both organic treatments was practically unchanging as to compare their values at the beginning and at the end of the experiment.

The content of Mehlich-3 extractable magnesium $\left(\mathrm{Mg}_{\mathrm{Me} 3}\right)$ in the soil of the ORGFYM treatment increased significantly $(P<0.05)$ under the influence of cattle manure. For the ORG treatment, the content of $\mathrm{Mg}_{\mathrm{Me} 3}$ did not decrease over seven years, rather had the increasing tendency; this could be found on the Mg-rich parent material (dolomitic moraine) of the experiment area.

The content of Mehlich-3 extractable manganese $\left(\mathrm{Mn}_{\mathrm{Me} 3}\right)$ in the soils did not change during the experiment period although for the ORGFYM treatment during the crop rotation with manure about $1.2 \mathrm{~kg} \mathrm{ha}^{-1}$ $\mathrm{Mn}$ was applied. The content of copper $\left(\mathrm{Cu}_{\mathrm{Me} 3}\right)$ in the soil decreased significantly $(P<0.05)$ for the both $\mathrm{ORG}$ and ORGFYM treatments. The contents of hot-water extractable boron (B) in the soil at the beginning and at the end of the experiment were compared. Results showed that by the ORG treatment B content decreased significantly $(P<0.05)$, and showed the decreasing tendency for the ORGFYM treatment.
Microbial communities in the soil. Microorganisms functioning in the rhizosphere are particularly important for plant nutrition as they provide plants not only with available nitrogen, phosphorus, and potassium but also with physiologically active substances that stimulate plant growth. Microorganisms are the most important degraders of organic material in the soil (Bakšienè et al., 2014; Blanchet et al., 2016). In organic systems, plant production depends primarily on nutrient cycling in soils that are controlled by microbes and soil enzymes (Monokrousos et al., 2006). The higher diversity of microbial communities and their activities were observed in soils treated with organic amendments, especially with FYM (Parham et al., 2002; Zaller, Köpke, 2004; Watts et al., 2010; Scherer et al., 2011).

The results of the microbiological investigations, carried out in the present experiment, showed that the application of FYM in the organically managed crop rotation significantly $(P<0.05)$ favoured the microbial activities in the soil (Järvan et al., 2014; Järvan, Edesi, 2015). Under the influence of FYM, the count of total bacteria in the soil increased by $19 \%$, as an average of experimental years (Järvan et al., 2014). Some microbial strains react especially strongly, the counts of cellulose decomposing bacteria and nitrifying bacteria increased by $45 \%$ and $122 \%$, respectively (Järvan et al., 2014; Järvan, Edesi, 2015). Also, the dehydrogenase activity which according to Wolinska and Stepniewska (2012) is one of the most important bioindicators for soil fertility increased significantly (by 23\%) when in organically managed crop rotation FYM was applied (Järvan et al., 2014).

Crop yields. Potato. Depending on the weather conditions, the yields of marketable tubers varied highly between years of the experiment (Table 4). In 2008, 2009 and 2014, the lowest yields for both organic treatments were harvested. In July-August 2008 and 2009 , there prevailed rainy periods propitious for rapid and severe development of potato late blight which too early damaged haulm of potatoes. This resulted in strongly decreasing yields of tubers. In 2014, the area of organically cultivated potato was very heavily infested with weeds (especially with Elytrigia repens, Sonchus arvensis and Cirsium arvense) which almost fully shaded and suppressed potato plants. In 2010-2013, the

Table 4. The crop yields and sum of the metabolizable energy (ME) calculated from yields of the organically managed crop rotation during the experiment period (2008-2014)

\begin{tabular}{|c|c|c|c|c|c|c|c|c|c|}
\hline \multirow{2}{*}{$\begin{array}{c}\text { Crop, } \\
\text { treatment }\end{array}$} & \multicolumn{7}{|c|}{ Yield t ha-1 } & \multicolumn{2}{|c|}{ 2008-2014 } \\
\hline & 2008 & 2009 & 2010 & 2011 & 2012 & 2013 & 2014 & $\mathrm{tha}^{-1}$ & ME GJ ha ${ }^{-1}$ \\
\hline \multicolumn{10}{|c|}{ Potato } \\
\hline ORG & 11.7 & 7.1 & 23.3 & 26.2 & 25.2 & 23.1 & 2.9 & 17.1 & 47.8 \\
\hline ORGFYM & 18.9 & 14.0 & 33.5 & 33.3 & 34.2 & 37.7 & 10.5 & 26.0 & 69.2 \\
\hline Difference & $7.2 *$ & $6.9^{*}$ & $10.2 *$ & $7.1 *$ & $9.0^{*}$ & $14.6^{*}$ & $7.6^{*}$ & $8.9^{*}$ & 21.4 \\
\hline \multicolumn{10}{|c|}{ Oats } \\
\hline ORG & 2.46 & 2.22 & 2.76 & 1.87 & 1.98 & 4.00 & 2.85 & 2.59 & 26.5 \\
\hline ORGFYM & 3.29 & 2.92 & 3.54 & 1.90 & 3.42 & 4.39 & 2.88 & 3.19 & 32.6 \\
\hline Difference & $0.83 *$ & $0.70^{*}$ & $0.74 *$ & 0.03 & $1.44 *$ & 0.39 & 0.03 & $0.60 *$ & 6.1 \\
\hline \multicolumn{10}{|c|}{ Barley } \\
\hline ORG & 1.26 & 1.96 & 1.05 & 0.93 & 1.50 & 1.86 & 1.44 & 1.43 & 16.0 \\
\hline ORGFYM & 1.26 & 2.37 & 1.39 & 1.08 & 1.91 & 1.50 & 1.56 & 1.58 & 17.7 \\
\hline Difference & 0 & $0.41^{*}$ & $0.34 *$ & 0.15 & $0.41 *$ & $-0.36^{*}$ & 0.12 & 0.15 & 1.7 \\
\hline \multicolumn{10}{|c|}{ Rye } \\
\hline ORG & 3.01 & 3.20 & 3.10 & 1.66 & 2.76 & 2.06 & 3.94 & 2.82 & 33.0 \\
\hline ORGFYM & 3.00 & 3.24 & 3.10 & 1.91 & 3.07 & 1.97 & 4.03 & 2.90 & 33.9 \\
\hline Difference & 0.01 & 0.04 & 0 & $0.25^{*}$ & 0.31 & 0.09 & 0.09 & 0.08 & 0.9 \\
\hline
\end{tabular}

Crop rotation (5 years): potato $\rightarrow$ oats $\rightarrow$ barley with undersown clover $\rightarrow$ clover as green manure $\rightarrow$ rye; ORG - organic without manure, ORGFYM - organic with farmyard cattle manure; ${ }^{*}-P<0.05$. 
potato yields for the ORG treatment varied in the range of 23-26 tha-1 and these for the ORGFYM treatment in the range of 33-38 $\mathrm{t} \mathrm{ha}^{-1}$. As the average of 2008-2014, potato tuber yield from the ORG treatment amounted to $17 \mathrm{tha}^{-1}$ and from the ORGFYM treatment $26 \mathrm{tha}^{-1}$, i.e. the application of cattle manure at a rate of $60 \mathrm{t} \mathrm{ha}^{-1}$ increased the yield of marketable tubers by $52 \%$.

Oats. Under the organic cultivation, the relatively fertile soil at Olustvere proved quite agreeable for oats: the grain yields during the experimental period (except 2011) amounted from 2.0 up to $4.0 \mathrm{t} \mathrm{ha}^{-1}$ for the ORG treatment and from 2.9 up to $4.4 \mathrm{t} \mathrm{ha}^{-1}$ for the ORGFYM treatment. In 2011, the oat yields for the both treatments remained low $\left(1.9 \mathrm{t} \mathrm{ha}^{-1}\right)$, because the weather conditions at the earlier growth stages were unfavourable - the first 10 days of June were very hot (as average $22.7^{\circ} \mathrm{C}$ ) and the drought lasted for three weeks. As the average for the period 2008-2014, the yield of oats in the ORGFYM treatment, resulting from the aftereffect of manure, was by $0.6 \mathrm{t} \mathrm{ha}^{-1}$ or $23 \%$ higher than for the ORG treatment.

Barley. Due to the reduced sowing rate of barley by reason of clover sowing under it, the grain yields remained low: in the range of $0.9-2.0 \mathrm{t} \mathrm{ha}^{-1}$ for the ORG treatment, and 1.1-2.4 $\mathrm{tha}^{-1}$ for the ORGFYM treatment. Although as average for 2008-2014, the yield of barley for the ORGFYM treatment was $0.15 \mathrm{t} \mathrm{ha}^{-1}$ higher, the difference is not significant $(P>0.05)$. That is to say, the significant positive second-year aftereffect of cattle manure was lacking.
Rye. Rye, in general, is not very sensitive to soil fertility. As was shown in our experiment, the grain yields of 3-4 $\mathrm{t} \mathrm{ha}^{-1}$ were not rare for the rye cultivation without nutrient input. The lower yields, exceptionally, were harvested in 2011 and 2013 due to the very hard conditions of wintering which decreased growth density of rye plants. The manure application was made many years before rye cultivation, thus it had no influence on rye yields. The yields of the ORG and ORGFYM treatments were practically similar, about $2.8-2.9 \mathrm{t} \mathrm{ha}^{-1}$ as the average for the 7-year experimental period.

Metabolizable energy of crop yields. The summarized metabolizable energy (ME) of the yields gathered from the crop rotation fields amounted to 123.3 GJ for the ORG treatment and 153.4 GJ for the ORGFYM treatment (Table 4). Thus, the application of $60 \mathrm{tha}^{-1}$ straw-based cattle manure every fifth year resulted in an extra income of 30 GJ metabolizable energy during the crop rotation.

Nutrient balances. The nutrient amounts removed with yields (output) in total during the crop rotation were the highest for potassium - 105 and $149 \mathrm{~kg} \mathrm{ha}^{-1}$, as the average of 2008-2014 for the ORG and ORGFYM treatments, respectively (Table 5). Among crops, the highest amounts of nutrients ( $\mathrm{P}, \mathrm{K}, \mathrm{Ca}$ and $\mathrm{Mg}$ ) were removed with potato tubers harvested. As an average of the 7-year experimental period, from the ORG treatment with potato there was yearly removed $10.7 \mathrm{~kg} \mathrm{ha}^{-1} \mathrm{P}, 81.1 \mathrm{~kg} \mathrm{ha}^{-1} \mathrm{~K}$, $2.8 \mathrm{~kg} \mathrm{ha}^{-1} \mathrm{Ca}$ and $5.1 \mathrm{~kg} \mathrm{ha}^{-1} \mathrm{Mg}$. From the ORGFYM

Table 5. The nutrient removal with yields during 2008-2014 and nutrient balances for the crop rotation

\begin{tabular}{|c|c|c|c|c|c|c|c|c|c|c|c|}
\hline \multirow{2}{*}{ Treatment } & \multirow{2}{*}{ Nutrient } & \multicolumn{7}{|c|}{$\begin{array}{l}\text { Removal with yields, total for all crops of the rotation } \\
\qquad \mathrm{kg} \mathrm{ha}^{-1}\end{array}$} & \multicolumn{3}{|c|}{$\begin{array}{l}\text { Average for 5-year crop rotation } \\
\qquad \mathrm{kg} \mathrm{ha}^{-1}\end{array}$} \\
\hline & & 2008 & 2009 & 2010 & 2011 & 2012 & 2013 & 2014 & output & input & balance \\
\hline \multirow{4}{*}{ ORG } & $\mathrm{P}$ & 33.8 & 31.0 & 39.2 & 33.0 & 38.3 & 41.4 & 30.1 & 35.3 & & -35 \\
\hline & $\mathrm{K}$ & 78.8 & 58.2 & 130.2 & 137.7 & 159.6 & 133.4 & 40.3 & 105.4 & & -105 \\
\hline & $\mathrm{Ca}$ & 4.4 & 3.3 & 7.9 & 9.0 & 10.9 & 8.2 & 7.1 & 7.3 & & -7 \\
\hline & $\mathrm{Mg}$ & 13.2 & 10.9 & 15.0 & 13.7 & 12.6 & 16.4 & 8.5 & 12.9 & & -13 \\
\hline \multirow{4}{*}{ ORGFYM } & $\mathrm{P}$ & 39.2 & 38.3 & 50.8 & 34.4 & 51.0 & 48.0 & 37.0 & 42.7 & 61 & +18 \\
\hline & $\mathrm{K}$ & 114.5 & 89.5 & 173.0 & 173.9 & 220.0 & 194.1 & 75.4 & 148.6 & 166 & +17 \\
\hline & $\mathrm{Ca}$ & 5.0 & 3.2 & 10.1 & 6.9 & 11.2 & 7.4 & 7.9 & 7.4 & 130 & +123 \\
\hline & $\mathrm{Mg}$ & 16.1 & 13.5 & 17.2 & 16.5 & 16.5 & 19.4 & 10.8 & 15.7 & 56 & +40 \\
\hline
\end{tabular}

ORG - organic without manure, ORGFYM - organic with farmyard cattle manure

treatment, the following nutrient amounts were removed from fields with potato tubers: $\mathrm{P} 15.6 \mathrm{~kg} \mathrm{ha}^{-1}$ $\mathrm{P}, 121.3 \mathrm{~kg} \mathrm{ha}^{-1} \mathrm{~K}, 3.0 \mathrm{~kg} \mathrm{ha}^{-1} \mathrm{Ca}$ and $7.0 \mathrm{~kg} \mathrm{ha}^{-1} \mathrm{Mg}$. The organic management without nutrient input, i.e. the ORG treatment in this case, resulted in strongly negative balance of all nutrients investigated. In that situation, a consistent trend to the soil fertility worsening with high probability takes place. For the ORGFYM treatment where solid cattle manure at a rate of $60 \mathrm{t} \mathrm{ha}^{-1}$ during 5 -year crop rotation was applied, the balance calculations showed small surpluses in phosphorus and potassium, and the greatest one in calcium. Consequently, to sustain and/or to improve the nutrient balance in the organically managed soils, the regular application of FYM is recommended - primarily utilizing manure producible in own farm, and/or purchasing it from other farms.

Profitability of organic management. Based on the seven-year average differences between crop yields of the ORGFYM and ORG treatments (Table 4), the costs and incomes for the additional production during the crop rotation, resulting from the use of FYM, were calculated (Table 6). The income for additional production
Table 6. The income-costs of additional production depending on the transportation distance of purchased manure

\begin{tabular}{ccc}
\hline $\begin{array}{c}\text { Manure } \\
\text { transportation } \\
\text { distance } \\
\mathrm{km}\end{array}$ & \multicolumn{2}{c}{$\begin{array}{c}\text { Income-costs } \\
€ \text { ha }^{-1} \text { for 5-year crop rotation }\end{array}$} \\
\cline { 2 - 3 } $1^{\mathrm{C}}$ & conventional $^{\mathrm{A}}$ & organic $^{\mathrm{B}}$ \\
5 & 151 & 869 \\
10 & -359 & 359 \\
15 & -491 & 227 \\
20 & -617 & 101 \\
\hline
\end{tabular}

Note. ${ }^{\mathrm{A}}$ - the products are sold at conventional prices; ${ }^{\mathrm{B}}-$ the products are sold at raised prices for organic products; $\mathrm{C}-$ monetary value of manure as farm's own production was not included in the calculation.

is calculated at two price levels: for conventional and for organic products. The buying up prices for the conventional products in October 2016 were as follows: for cereals (Baltic Agro Ltd.) - $128 € \mathrm{t}^{-1}$ oats, $115 € \mathrm{t}^{-1}$ barley and $108 € \mathrm{t}^{-1}$ rye; for potato (commercial association 
Talukartul) $-110 € \mathrm{t}^{-1}$. For organically grown cereals, the buying up prices at the same time were as follows: oats $-235 € \mathrm{t}^{-1}$, barley and rye $-200 € \mathrm{t}^{-1}$ (Baltic Agro Ltd.). The suitable price for organic potato is $200 € \mathrm{t}^{-1}$ (Paivel, Järvan, 2012).

The additional costs depending on the manure transportation distance were subtracted from the values of income; the results are presented in Table 6. It was evident that by selling organically cultivated products at conventional prices, the purchase of manure from other farmers did not prove to be cost-effective. The application of on-farm produced manure was profitable even if it sold products at the conventional products prices. This resulted in a profit of $151 € \mathrm{ha}^{-1}$ as a total for the whole crop rotation; besides this, several above-mentioned processes in the soil were favoured under the influence of manure. If the surplus yield were sold at higher prices valid for organic food, it would be profitable to purchase manure from the neighbouring farms located even at a 15-km distance.

\section{Conclusions}

1. On a sandy loam Albic Stagnic Luvisol $(L V a b-s t)$, the organic cultivation without nutrient input during a seven-year period caused a significant $(P<0.05)$ decrease in the contents of mobile potassium $(\mathrm{K})$, copper $(\mathrm{Cu})$ and boron $(\mathrm{B})$ in the soil. Also, a light tendency to the decrease of organic carbon $\left(\mathrm{C}_{\text {org }}\right)$ content in the soil became evident.

2. The application of $8.3 \mathrm{t} \mathrm{ha}^{-1}$ organic dry matter as solid cattle farmyard manure (FYM) for a five-year crop rotation was environmentally advantageous from the viewpoint of soil fertility and biodiversity. Under the influence of manure, the significant $(P<0.05)$ increase in phosphorus and magnesium, and a tendency towards increase of potassium and $\mathrm{C}_{\text {oro }}$ contents in the soil were established. Also, the microbial life in the soil was favoured when manure was used in organically managed crop rotation - the communities of cellulose decomposing bacteria, nitrifying bacteria and total bacteria increased significantly $(P<0.05)$.

3. Under direct influence of the manure application, the marketable yield of potato tubers increased by $8.9 \mathrm{t} \mathrm{ha}^{-1}$, or $52 \%$, as the average for the experiment period. The after-effect of manure increased the average yield of oats by $23 \%$ and that of barley by $10 \%$. The application of manure every fifth year resulted in an extra income of 30 GJ metabolizable energy during the crop rotation.

4. The economic calculations showed that the application of on-farm produced manure was profitable even if the farm sold products at conventional products' prices. If the surplus yield was sold at higher prices valid for organic food, it would be profitable to purchase manure from the neighbouring farms located even at a 15-km distance.

\section{Acknowledgements}

This paper presents research findings obtained through the long-term research project "The influence of organic and conventional farming on soil fertility, biodiversity and on crops yield and quality" funded by the Estonian Ministry of Rural Affairs (former Estonian Ministry of Agriculture). The authors would like to thank Liina Edesi, Miralda Paivel and Enno Koik for their help.

Received 20032017

Accepted 02102017

\section{References}

1. AOAC. 1990. AOAC Official methods of analysis $\left(15^{\text {th }}\right.$ ed.). Association of Official Analytical Chemists, USA.

2. Asai M., Langer V. 2014. Collaborative partnerships between organic farmers in livestock-intensive areas of Denmark. Organic Agriculture. 4 (1): 63-77. https://doi.org/10.1007/s13165-014-0065-3

3. Bakšienė E., Ražukas A., Repečkienè J., Titova J. 2014. Influence of different farming systems on the stability of low productivity soil in Southeast Lithuania. ZemdirbysteAgriculture. 101 (2): 115-124. https://doi.org/10.13080/z-a.2014.101.015

4. Berger K. C., Truog E. 1939. Boron determination in soils and plants. Industrial Engineering Chemistry and Analytical Edition 11 (10): 540-545.

https://doi.org/10.1021/ac50138a007

5. Blanchet G., Gavazov K., Bragazza L., Sinaj S. 2016. Responses of soil properties and crop yields to different inorganic and organic amendments in a Swiss conventional farming systems. Agriculture, Ecosystems and Environment, 230 (16): 116-126. https://doi.org/10.1016/j.agee.2016.05.032

6. Diacono M., Montemurro F. 2010. Long-term effects of organic amendments on soil fertility. A review. Agronomy for Sustainable Development, 30 (2): 401-422. https://doi.org/10.1051/agro/2009040

7. Dunjana N., Nyamugafata P., Shumba A., Nyamangara J., Zingore S. 2012. Effects of cattle manure on selected soil physical properties of smallholder farms on two soils of Murewa, Zimbabwe. Soil Use and Management, 28(2): 221-228.

https://doi.org/10.1111/j.1475-2743.2012.00394.x

8. Fageria N. K. 2012. Role of soil organic matter in maintaining sustainability of cropping systems. Communications in Soil Science and Plant Analvsis. 43: 2063-2113.

https://doi.org/10.1080/00103624.2012.697234

9. Foissy D., Vian J. F., David C. 2013. Managing nutrient in organic farming system: reliance of livestock production for nutrient management of arable farmland. Organic Agriculture. 3 (3): 183-199. https://doi.org/10.1007/s13165-014-0060-8

10. Järvan M., Edesi L. 2015. Nitrogen cycle bacteria in soils of organically and conventionally managed crop rotations. Zemdirbyste-Agriculture, 102 (1): 15-22. https://doi.org/10.13080/z-a.2015.102.002

11. Järvan M., Edesi L., Adamson A., Võsa T. 2014. Soil microbial communities and dehydrogenase activity depending on farming systems. Plant, Soil and Environment, 60 (10): 459-463.

12. Järvan M., Vettik R., Adamson A. 2017. Assessment of plant nutrients' dynamics in organically and conventionally managed soils by means of different extraction methods. Acta Agriculturae Scandinavica, Section B: Soil and Plant Science. 67 (3): 191-201 https://doi.org/10.1080/09064710.2016.1242645

13. Koik E., Tamm K., Vettik R., Viil P. 2009. Expenses of carrying of plant nutrition elements from storage to the field, depending on the type of fertilizer. Agronomy 2009. Tamm S., Schmidt R. (eds.). Tartu, Estonia, p. 212-217 (in Estonian).

14. Körschens M., Weigel A., Schulz E. 1998. Turnover of soil organic matter (SOM) and long-term balances - tools for evaluating sustainable productivity of soils. Journal of Plant Nutrition and Soil Science. 161 (4): 409-424. https://doi.org/10.1002/jpln.1998.3581610409

15. Masilionytè L., Maikštènienè S. 2016. The effect of alternative cropping systems on the changes of the main nutritional elements in the soil. Zemdirbyste-Agriculture, $103(1): 3-10$ https://doi.org/10.13080/z-a.2016.103.001

16. Maughan M. W., Flores J. P. C., Anghinoni I., Boller G., Fernández F., Tracy B. 2009. Soil quality and corn yield under crop-livestock integration in Illinois. Agronomy Journal. 101 (6): 1503-1510 https://doi.org/10.2134/agronj2009.0068 
17. Mehlich A. 1984. Mehlich-3 soil test extractant: a modification of Mehlich-2 extractant. Communications in Soil Science and Plant Analysis. 15: 1409-1416. https://doi.org/10.1080/00103628409367568

18. Monokrousos N., Papatheodorou E. M., Diamantopoulos J. D., Stamou G. P. 2006. Soil quality variables in organically and conventionally cultivated field sites. Soil Biology and Biochemistrv. 38: 1282-1289.

https://doi.org/10.1016/j.soilbio.2005.09.023

19. Oinus N. 2012. Strategic planning in organic agriculture. Estonian Foundation of Organic Agriculture, $41 \mathrm{p}$. (in Estonian).

20. Oll Ü., Tölp S. 1997. Guide for the calculation of energy content in feeds. Estonian Agricultural University, 83 p. (in Estonian).

21. Paivel M., Järvan M. 2012. Does the farmer manage organically without subsidies? Maamajandus (Rural Management), p. 4-7 (in Estonian).

22. Parham J., Deng S., Raun W., Johnson G. 2002. Longterm cattle manure application in soil. I. Effect on soil phosphorus levels, microbial biomass $\mathrm{C}$, and dehydrogenase and phosphatase activities. Biology and Fertility of Soils, 35 (5): 328-337.

23. Scherer H. W., Metker D. J., Welp G. 2011. Effect of longterm organic amendments on chemical and microbial properties of a luvisol. Plant, Soil and Environment, 57 (11): 513-518.

24. Smith K. A., Williams A. G. 2016. Production and management of cattle manure in the UK and implications for land application practice. Soil Use and Management, 32 (S1): 73-82. https://doi.org/10.1111/sum.12247

25. Stockdale E. A., Watson C. A. 2009. Biological indicators of soil quality in organic farming systems. Renewable Agriculture and Food Systems. 24 (4): 308-318. https://doi.org/10.1017/S1742170509990172

26. Simon T., Czakó A. 2014. Influence of long-term application of organic and inorganic fertilizers on soil properties. Plant, Soil and Environment, 60 (7): 314-319.

27. Tabatabai M. A. 1982. Soil enzymes. Page A. L. et al. (eds.). Methods of soil analysis, part 2. American Society of Agronomy and Soil Science Society of America.
28. Tamm K., Vettik R. 2008. Case study: Economics of spring feeding in grassland. Agronomy Research, 6 (spec. iss.): 387-396.

29. Tamm K., Vettik R. 2011. Allocation of different types of manure in Estonia and monetary value of manure nutrients. Conference Agronomy 2010-2011. Saku, Estonia, p. 231236 (in Estonian).

30. Tripolskaja L., Baksiene E., Razukas A., Sidlauskas G. 2016. How organic fertilizers change chemical element leaching: a summary of the lysimeter studies in Lithuania 1987-2014. Polish Journal of Environmental Studies, 25 (6): 2589-2599. https://doi.org/10.15244/pjoes/63736

31. Watson C. A., Bengtsson H., Ebbesvik M., Løes A.-K., Myrbeck A., Salomon E., Schroder J., Stockdale E. A. 2002. A review of farm-scale nutrient budgets for organic farms as a tool for management of soil fertility. Soil Use and Management. 18: 264-273. https://doi.org/10.1079/SUM2002127

32. Watson C. A., Stockdale E. A. 2013. Long-term management of nutrients in organic farming - principles and practice. NJF Report, 9: 23-26.

33. Watts D. B., Torbert H.A., Feng Y., Prior S. A. 2010. Soil microbial community dynamics as influenced by composted dairy manure, soil properties, and landscape position. Soil Science, 175 (10): 474-486. https://doi.org/10.1097/SS.0b013e3181f7964f'

34. Wolinska A., Stepniewska Z. 2012. Dehydrogenase activity in the soil environment. Canuto R. A. (ed.). Dehydrogenases, p. 183-210. https://doi.org/10.5772/48294

35. Wortman S. E., Galusha T. D., Mason S. C., Francis C. A. 2012. Soil fertility and crop yields in long-term organic and conventional cropping systems in Eastern Nebraska. Renewable Agriculture and Food Systems. 27 (3): 200-216. https://doi.org/10.1017/S1742170511000317

36. Zaller J. G., Köpke U. 2004. Effects of traditional and biodynamic farmyard manure amendment on yields, soil chemical, biochemical and biological properties in a long-term field experiment. Biology and Fertility of Soils, 40 (4): 222-229.

https://doi.org/10.1007/s00374-004-0772-0

ISSN 1392-3196 / e-ISSN 2335-8947

Zemdirbyste-Agriculture, vol. 104, No. 4 (2017), p. 321-328

DOI $10.13080 / \mathrm{z}-\mathrm{a} .2017 .104 .041$

\title{
Ekologinėje sëjomainoje panaudoto mëšlo svarba ir ekonominis efektyvumas
}

\author{
M. Järvan, R. Vettik, K. Tamm \\ Estijos žemès ūkio augalų tyrimų institutas
}

\begin{abstract}
Santrauka
Ekologiškai auginamų augalų nauda yra susijusi su dirvožemio derlingumo išsaugojimu, kuris priklauso nuo dirvožemio organiniu medžiagų kiekio. Mèšlas yra viena iš vertingesniu organinių trą̧ǔ, palaikančiu dirvožemio derlingumą taikant alternatyvias ūkininkavimo sistemas. Siekiant išsamiai ištirti méšlo ittaką, lauko eksperimentas atliktas smèlingame priemolyje, pajaurejusiame stagniškame išplautžemyje (IDj2-e). Penkiu lauku sèjomainos augalai (bulvès $\rightarrow$ avižos $\rightarrow$ miežiai $\rightarrow$ dobilai $\rightarrow$ rugiai) buvo ekologiškai auginti be méšlo (ORG) ir su mèšlu (ORGM). Bulvès buvo tręštos galvijų méšlu $\left(8,3 \mathrm{tha}^{-1}\right.$ organinių sausujų medžiagų). Mèšlas buvo paskleistas ant bulvių priešselio rugių ražienų ir užartas. Abiejuose variantuose ị dirvą buvo ịterpta visa dobilų ir šiaudu masè. Per septynerių metụ tyrimų laikotarpị nebuvo nustatyta reikšmingų dirvožemio organinès anglies $\left(\mathrm{C}_{\text {org }}\right)$ sudèties pokyčiu. ORG variante kalio, vario ir boro kiekis dirvožemyje reikšmingai $(P<0,05)$ sumažèjo. Mèšso panaudojimas labai padidino fosforo ir magnio kiekị dirvožemyje. Dèl mešlo ịtakos bulvių, avižu ir miežiu derlius padidèjo atitinkamai 52, 23 ir $10 \%$; tai leido per sèjomainą papildomai gauti $30 \mathrm{GJ}$ apykaitinès energijos. Ekonominiai skaičiavimai parodè, kad ūkyje pagaminto méšlo panaudojimas buvo pelningas, net jei derlius buvo parduotas kaip neekologiškas. Jei derlius parduodamas kaip ekologiškas produktas, būtų pelninga, jei ịsigyjamo měšlo gabenimo atstumas ị laukus būtų iki $15 \mathrm{~km}$.
\end{abstract}

Reikšminiai žodžiai: derlius, dirvožemio mitybinès medžiagos, kietasis galvijų mėšlas, organinė anglis, pelnas. 